\title{
KAJIAN SENSASI KENYAMANAN TERMAL DAN KONSUMSI ENERGI DI TAMAN SRIGUNTING KOTA LAMA SEMARANG
}

\author{
Bambang Suyono*, Eddy Prianto * \\ *)Departemen Arsitektur, Fakultas Teknik, Universitas Diponegoro
}

\begin{abstract}
An active park is indicated by the people activities and supported by the elements of street furniture. Hardware and software elements are the inside parts which play an important role in creating the comfort, wherein supported by the sustainability of the exterior gardens (outside the building) in the tropics play a very important role in the microclimate environment. The phenomenon of the relationship between conservation of ancient areas in the tropics such as Semarang city and the national energy crisis in the last decade is very interesting to be explored. As the development of instructional subject matter of Advance Landscape, Architecture Design and Building Physics in the basic of this research, our research question is: How far is the relationship between the energy profile consumption (lamp lighting) to comfort in the park? Two methods used in the field observation, the measurement of climate aspect to find out the micro climate profile and the distribution of questionnaire in the park to discover the user comfort sensation. The results found Taman Srigunting in the old city of Semarang is categorized both as a passive and active park, used for prominent activity in photography. These parks also influence the surrounding nature by decreasing the microclimate such as air temperature and humidity in the evening in the amount of $76 \%$ and $57 \%$ in the day. The air temperature went down from 34.8 C to 28.7 C. The micro climatic conditions and characteristics of energy consumption level was significant with the visitors comfort sensations, where in $56 \%$ visitors felt comfortable and only $4 \%$ felt the sensation of heat.
\end{abstract}

Keywords: Park, Thermal Comfort, Energy, Old City of Semarang, Micro Climate

\section{PENDAHULUAN}

Pengujian kenyamanan termal ruang luar pada Taman Sri Gunting yang berada disekitar Gereja Blenduk menjadi salah satu alat ukur tingkat kenyamanan pada kawasan Kota Lama. Kenyamanan terdiri dari kenyamanan ruang, kenyamanan pengelihatan, kenyamanan pendengaran (akustik) dan

kenyamanan termal (Karyono, 2010). Salah satu tingkat kenyamanan yang berpengaruh terhadap aktivitas manusia adalah kenyamanan termal. Menurut Karyono (2010) kenyamanan termal adalah respon manusia terhadap rangsangan suhu yang diterima dari lingkungan. Respon yang ditunjukkan manusia adalah adanya rasa panas atau dingin. Kenyamanan termal juga dapat diartikan sebagai presepsi manusia terhadap kondisi termal yang dirasakan. Dalam mengkaji kenyamanan termal, dapat dilakukan baik di dalam ruangan

Kenyamanan yang ada pada ruang luar lebih sulit untuk dikaji jika dibandingkan dengan mengkaji kenyamanan ruang dalam karena kondisi termal ruang luar dipengaruhi oleh banyak faktor. Salah satu faktor yang memiliki pengaruh besar pada kenyamanan ruang luar adalah suhu udara suatu kawasan (Sangkertadi, 2013). Kondisi lingkungan luar yang nyaman akan membuat orang - orang lebih nyaman dalam melakukan aktifitas di luar bangunan. Dengan adanya aktifitas di luar bangunan diharapkan dapat meningkatkan interaksi sosial masyarakat dalam mewujudkan keserasian sosial antar masyarakat.

Pemerintah Kota Semarang dalam beberapa tahun terakhit ini (Pemkotsemarang, 2016) sedang gencar-gencarnya melakukan revitalisasi kawasan kota lama Semarang. Dalam pengamatan penulis, kegiatan malamhari lebih terkonstrasi pada kawasan seputar Gereja Blenduk dan taman Srigunting. Penerangan energy listrik menjadi andalan utama untuk membuat kawasan lebih terang dan diharapkan hidup/ penuh aktifitas di malam hari. Sejauhmana peran penerangan dan rasa kenyamanan pelaku dalam taman ini ? Itulah yang menjadikan dasar dari penelitian ini

Tujuan dari penelitian ini didasari pada dua pertanyaan utama, pertama sejauh mana tingkat kenyamanan pelaku/pengunjung di taman Srigunting? Dan kedua, element-elemet disain aktif (penerangan dan lainnya) apa saja yang eksis di dalam taman dan seberapa jauh konsumsi energinya ?. Sehingga pertanyaan peneliti dari kedua hubungan variable tersebut adalah : Bagaimana hubungan antara karakter kenyamanan dan konsumsi energy di area taman ?

Batasan dan Obyek pengamatan ini adalah taman yang terletak di Kawasan Kota Lama, yaitu Taman Srigunting. Penelitian ini mengulas hubungan antara kenyamanan termal pada Taman Srigunting terhadap 
pengunjung dengan tingkat konsumsi energy listrik/ penerangan dalam taman.

\section{Pengertian Ruang Luar}

Ruang luar berfungsi sebagai wadah pembelajaran dan sosial, area bermain, serta sarana olahraga. Istiawan dan Kencana dalam bukunya menyatakan ruang luar adalah : Ruang yang terjadi dengan membatasi alam hanya pada bidang alas dan dindingnya, sedangkan atapnya dapat dikatakan tidak terbatas. Sebagai lingkungan luar buatan manusia, yang mempunyai arti dan maksud tertentu dan sebagai bagian dari alam. Arsitektur tanpa atap, tetapi dibatasi oleh dua bidang: lantai dan dinding atau ruang yang terjadi dengan menggunakan dua elemen pembatas. Hal ini menyebabkan bahwa lantai dan dinding menjadi elemen penting di dalam merencanakan ruang luar. (Istiawan dan Kencana,2006)

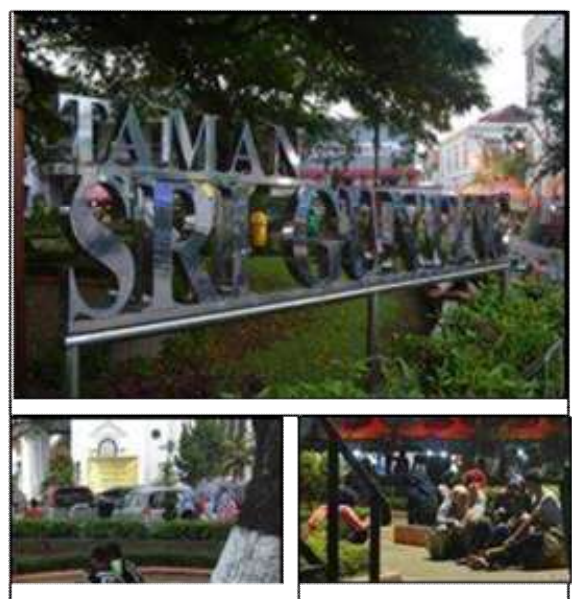

Gambar 1 : Visualisasi taman Srigunting dikawasan kota lama dan aktifitas disiang hari dan malam hari

\section{Ruang Terbuka}

Ruang Terbuka adalah ruang-ruang dalam kota atau wilayah yang lebih luas baik dalam bentuk area/kawasan maupun dalam bentuk area memanjang/jalur dimana dalam penggunaannya lebih bersifat terbuka yang pada dasarnya tanpa bangunan. Ruang terbuka terdiri atas ruang terbuka hijau dan ruang terbuka non hijau.(Kirmanto, 2008)

\section{Ruang Terbuka Hijau}

Ruang Terbuka Hijau (RTH) adalah area memanjang/jalur dan atau mengelompok, yang penggunaannya lebih bersifat terbuka, tempat tumbuh tanaman, baik yang tumbuh tanaman secara alamiah maupun yang sengaja ditanam. Ruang Terbuka Hijau (RTH) sendiri dapat dibagi menjadi dua:

Ruang Terbuka Hijau (RTH) Privat : RTH
milik institusi tertentu atau orang
perseorangan yang pemanfaatannya untuk

kalangan terbatas antara lain berupa kebun atau halaman rumah/gedung milik masyarakat/swasta yang ditanami tumbuhan.

Ruang Terbuka Hijau (RTH) Publik : RTH yang dimiliki dan dikelola oleh pemerintah daerah kota/kabupaten yang digunakan untuk kepentingan masyarakat secara umum.

\section{Ruang Terbuka Non Hijau}

Ruang Terbuka Non Hijau adalah ruang terbuka di wilayah perkotaan yang tidak termasuk dalam kategori RTH, berupa lahan yang diperkeras maupun yang berupa badan air. Rustam Hakim, (Hakim,2006) membagi ruang terbuka berdasarkan kegiatan yang terjadi sebagai berikut :

Ruang terbuka aktif, yaitu ruang terbuka yang mengundang unsur-unsur kegiatan di dalamnya, misalnya plaza, tempat bermain.

Ruang terbuka pasif, yaitu ruang terbuka yang di dalamnya tidak mengundang kegiatan manusia. Taman untuk rekreasi aktif dan pasif.

\section{Taman}

Dari pemahaman Ruang Terbuka Hijau (RTH) tersebut diatas, pemahaman taman berarti suatu area memanjang/jalur dan atau mengelompok, yang penggunaannya lebih bersifat terbuka, tempat tumbuh tanaman, baik yang tumbuh tanaman secara alamiah maupun yang sengaja ditanam. Serta dari pengelolaannya, bisa bersifat public ataupun privat. Sedangkan menurut Peraturan Menteri Pekerja Umum Nomor: 5/PRT/M/2008 tentang Pedoman Penyediaan dan Pemanfaatan Ruang Terbuka Hijau di Kawasan Perkotaan, definisi taman adalah lahan terbuka yang berfungsi sosial dan estetik sebagai sarana kegiatan rekreatif, edukasi atau kegiatan lain baik pada tingkat kota maupun lingkungan (DitjenPRDPU, 2008). Beberapa referensi yang di tulis Yunika dalam blogspotnya (Yunika, 2012), menambahkan pemahaman sebuah taman:

Pertama, Jenis taman terbagi menjadi 2 yaitu: taman aktif, yang memiliki fungsi sebagai tempat bermain dengan dilengkapi elemen-elemen pendukung taman bermain, dan taman pasif yang hanya dilengkapi elemen estetis saja hingga pada umumnya untuk menjaga keindahan taman diberikan pagar sebagai pengaman. Selain itu pada taman aktif maupun pasif biasanya dilengkapi oleh elemen-elemen penunjang yang dapat menunjang fungsi atau kegiatan yang ada di dalam taman tersebut. Elemen penunjang dasar yang terdapat pada taman biasanya berupa lampu dan keran air.

Kedua, taman adalah sebidang lahan berpagar yang digunakan untuk mendapatkan kesenangan, kegembiraan, dan kenyamanan. 
Ketiga, sedangkan pemahaman taman kota merupakan transisi antara perkembangan kota dan daerah pedesaan, yang terletak di luar konsentrasi penduduk. Taman kota dibentuk sebagai penyekat hijau untuk memisahkan berbagai penggunaan lahan dalam kota.

Menurut Susiloarifin dan Nurhayati. ada tiga macam taman kota berdasarkan aktifitasnya (Susiloarifin dan Nurhayati. 1994):

Taman untuk rekreasi aktif, yaitu taman untuk rekreasi aktif adalah taman yang didalamnya dibangun suatu kegiatan pemakai taman, sehingga pemakai taman secara aktif menggunakan fasilitas didalamnya, sekaligus memperoleh kesenangan, kesegaran, dan kebugaran, misalnya taman olah raga, aerobic, fitness, camping ground, taman bermain anak, taman pramuka, taman jalur jalan, kebun binatang, danau, pemancingan taman-taman kota dan sebagainya.

Taman untuk rekreasi pasif, adalah taman yang dibentuk agar dapat dinikmati keindahan dan kerindangannya, tanpa mengadakan aktivitas dan kegiatan apapun, misalnya waduk, hutan buatan, penghijauan tepi kali, jalur hijau, lapangan terbang, dan lainnya.

Gabungan antara taman untuk rekreasi aktif dan pasif. Dari keduanya ini, taman untuk rekreasi aktif dan pasif merupakan taman yang bisa dinikmati keindahan sekaligus ada fungsi lain dan dapat digunakan untuk mengadakan aktifitas, misalnya taman lingkungan. Taman lingkungan atau community park adalah suatu taman yang dibuat dan merupakan bagian dari suatu pemukiman, selain rumah ibadah, pasar, sekolah, dan lain-lainnya.

Jadi, Taman Kota merupakan ruang terbuka hijau di kawasan perkotaan yang memiliki nilai estetik sebagai landmark kota, menjadi sarana rekreatif maupun edukatif tempat masyarakat bersosial, dan berfungsi menjaga kelestarian ekosistem lingkungan. Terdapat beberapa Taman Kota di wilayah Kota Semarang. Pada penelitian ini akan membahas mengenai Taman Kota yang berada dikawasan Kota Lama Semarang sebagai salah satu kawasan yang memiliki nilai historis tinggi.

\section{Kenyamanan Thermal dan Parameter Iklim mikro \\ Faktor iklim mikro}

Menurut Karyono (2010) kenyamanan termal diartikan sebagai presepsi manusia terhadap kondisi termal dari lingkungannya. Dalam mengkaji kenyamanan termal, dapat dilakukan baik di dalam ruangan maupun di luar ruangan.
Kenyamanan termal dalam ruang (indoor) akan berbeda dengan kenyamanan termal luar ruang (outdoor). Kenyamanan termal indoor merupakan dampak yang ditimbulkan oleh pemilihan jenis material bangunan, bentuk dan atau orientasi bangunan itu sendiri, bukaan - bukaan, luasan bangunan dan lain lain (Prianto dan Depecker, 2002), (Amin et al, 2004). Sedangkan kenyamanan termal outdoor timbul dari pengaruh konfigurasi massa bangunan terhadap temperatur dalam sebuah kawasan, sehingga akhirnya didapat kenyamanan termal lingkungan (Muhammad dan Prianto, 2006) (Sangkertadi, 2013), (Brown dan Terry, 1995), (Ahmad dan Hidayat,-), (Hawa, 2016)

Faktor yang sangat berpengaruh dalam mengevalusi kondisi thermal suatu lingkungan adalah dengan mengamati iklim dalam kawasan tersebut. Lippsmeier (1994), menyatakan bahwa variable iklim yang berpenrauh terhadap kondisi kenyamanan thermal suatu kawasan adalah

\section{a. Temperature Udara}

Seperti yang ditulis oleh Huda (Muhammad dan Prianto, 2016), bahwa suhu nyaman untuk pribumi Indonesia berdasarkan penelitian Mom dan Wiesebrom (1940) adalah sejuk nyaman suhu antara

$20,5^{\circ} \mathrm{C}$ sampai dengan $22,8^{\circ} \mathrm{C}$ (TE), nyaman optimal suhu antara $22,8^{\circ} \mathrm{C}$ sampai dengan $25,8^{\circ} \mathrm{C}$ (TE) dan hangat nyaman suhu antara $25,8^{\circ} \mathrm{C}$ sampai dengan $27,1^{\circ} \mathrm{C}(\mathrm{TE})$.

\section{b. Kelembaban Udara}

Kelembaban udara yang nikmat untuk tubuh berkisar $40-70 \%$. Padahal di tempat-tempat seperti di tepi pantai, berkisar $80 \%$ - 98\%. Untuk itu diperlukan pengembangan lain demi rasa comfort tubuh. Dengan kata lain proses penguapan harus dipercepat. Jika kelembaban udara sudah jenuh, maka tubuh kita tidak bisa menguapkan keringat lagi (Frick dan Darmawan, 2007)

\section{c. Angin}

Kecepatan angin untuk kenyamanan dalam ruangan terdapat pada batas-batas kecepatan antara $0,1 \mathrm{~m} /$ detik sampai dengan $0,5 \mathrm{~m} /$ detik., apabila melebihi batas tersebut (diatas/dibawah) maka sensasi dikatakan tidak nyaman (netral). (Prianto dan Depecker 2002).

\section{Kenyamanan termal}

Secara prinsip parameter kenyaman termal seseorang tergantung pada factor lingkungan ( Suhu udara, kecepatan angina dan kelembaban) dan factor manusia (aktifitas dan pakaian). Keenam parameter ini dirumuskan oleh Fanger dengan indeks PMV (Prianto dan Depecker,2003).

Kenyamanan termal secara umum dikenal sebagai rasa nyaman terhadap situasi termik di 
lingkungan sekitar tubuh. Situasi kenyamanan termis senantiasa dihubungkan dengan situasi klimatik (Sangkertadi, 2013).

Kenyamanan dan perasaan nyaman adalah penilaian komprehensif seseorang terhadap lingkungannya. Manusia menilai kondisi lingkungan berdasarkan rangsangan yang masuk ke dalam dirinya melalui keenam indera melalui syaraf dan dicerna oleh otak untuk dinilai. Dalam hal ini yang terlibat tidak hanya masalah fisik biologis, namun juga perasaan. Suara, cahaya, bau, suhu dan lain-lain rangsangan ditangkap sekaligus, lalu diolah oleh otak. Kemudian otak akan memberikan penilaian relatif apakah kondisi itu nyaman atau tidak. Ketidaknyamanan di satu faktor dapat ditutupi oleh faktor lain (Karyono, 2010) Menurut Kolcaba (2003) aspek kenyamanan terdiri dari:

Kenyamanan fisik berkenaan dengan sensasi tubuh yang dirasakan oleh individu itu sendiri.

Kenyamanan psikospiritual berkenaan dengan kesadaran internal diri, yang meliputi konsep diri, harga diri, makna kehidupan, seksualitas hingga hubungan yang sangat dekat dan lebih tinggi.

Kenyamanan lingkungan berkenaan dengan lingkungan, kondisi dan pengaruh dari luar kepada manusia seperti temperatur, warna, suhu, pencahayaan, suara, dll.

Kenyamanan sosial kultural berkenaan dengan hubungan interpesonal, keluarga, dan sosial atau masyarakat (keuangan, perawatan kesehatan individu, kegiatan religius, serta tradisi keluarga).

\section{Konsumsi energy listrik dalam ruang terbuka}

Karakter kebutuhan energy listrik dalam bangunan dan luar bangunan tentunya berbeda. Dari ketentuan yang ada (Prianto, 2007) kebutuhan energy dalam bangunan terdapat dua kategori : Kebutuhan Energi karena konfigurasi Disain Aktif (AC, Lampu dan perlengkapan elektronik lainnya) dan konfigurasi Disain Pasif (element disain bangunan dan lansekap).

Berdasarkan SNI 03-6169-2011 (SNI, 2017)

Prosedur Audit Energi, definisi energi adalah kemampuan dari suatu sistem untuk melakukan kerja pada sistem yang lain. Sedangkan konsumsi energi adalah besarnya energi yang digunakan dalam periode waktu tertentu dan merupakan perkalian antara daya dan waktu operasi. Energi Listrik adalah energi akhir yang dibutuhkan bagi peralatan listrik untuk menggerakkan motor, lampu penerangan, memanaskan, mendinginkan ataupun untuk menggerakkan kembali suatu peralatan mekanik untuk menghasilkan bentuk energi yang lain.
Pengertian energi listrik adalah kemampuan untuk melakukan atau menghasilkan usaha listrik (kemampuan yang diperlukan untuk memindahkan muatan dari satu titik ke titik yang lain). Energi listrik dilambangkan dengan Watt. (Widjayanti, 2007)

\section{Pencahayaan Buatan}

Makna pencahayaan buatan bukanlah sekadar menyediakan lampu dan terangnya, tetapi lebih untuk membentuk suasana. Jadi, pencahayaan bukan hanya masalah praktis tapi juga estetis. Pencahayaan buatan diperlukan karena kita tidak dapat sepenuhnya tergantung dari ketersediaan pencahayaan alami. Pencahayaan buatan bersifat saling mendukung dengan pencahayaan alami. (Satwiko, 2004)

Pencahayaan buatan memerlukan energi. Ini menjadi salah satu kekurangan pencahayaan buatan terutama bila energi tersebut diperoleh dari sumber yang takterbarui seperti minyak bumi. Jika kita menyebut lampu, umumnya kita membatasi dan menekankan pada bagian yang menyala. (Satwiko, 2004)

Setiap lampu dibuat dengan tujuan tertentu dan mempunyai arah yang disesuaikan dengan tujuannya. Beberapa istilah lampu sesuai arah dan luas sinarnya adalah :

Penyinar atas (up-lighter), lampu yangmenyorot ke atas.

Penyinar bawah (down-lighter), lampu yangmenyorot ke bawah.

Penyorot sempit (spot light), lampu dengansudut sinar $<30^{\circ}$.

Penyorot lebar (flood light), lampu dengansudut sinat $>30^{\circ}$.

Penyiram dinding (wall-wash light), lampuuntuk menyiram bidang vertical dengancahaya.

Menurut Istiawan (2006), pencahayaan dibagi menjadi tiga fungsi yaitu :

Pencahayaan Umum, Pencahayaan umum atau general lighting atau kadang disebut ambience lighting merupakan fungsi dasar cahaya, yaitu cahaya dituntut harus ada di seluruh ruang tertentu. Cahaya di sini berfungsi sebagai penerangan utama, sifat penyinarannya merata dan lampu yang digunakan biasanya lampu yang memiliki watt besar agar cahayanya cukup untuk menerangi seluruh bagian dalam ruang.

Pencahayaan Khusus, Pencahayaan khusus atau task lighting adalah pencahayaan setempat dengan tujuan untuk mendukung aktivitas yang membutuhkan cahaya lebih 
terang seperti membaca, memasak, dan pekerjaan lainnya. Lampu yang digunakan sebaiknya mempunyai sinar cukup terang dan dapat difokuskan pada titik tertentu.

Pencahayaan Dekoratif, Cahaya lebih berperan dalam segi estetika. Cahaya berfungsi menonjolkan nilai keindahan obyek pada ruang atau desain dari ruang itu sendiri. Lampu dapat diletakkan, misalnya di dinding yang disebut sebagai lampu dinding, di lantai sehingga cahaya lampu mengarah ke atas, atau sebagai latar suatu obyek. (Istiawan \& Kencana, 2006)

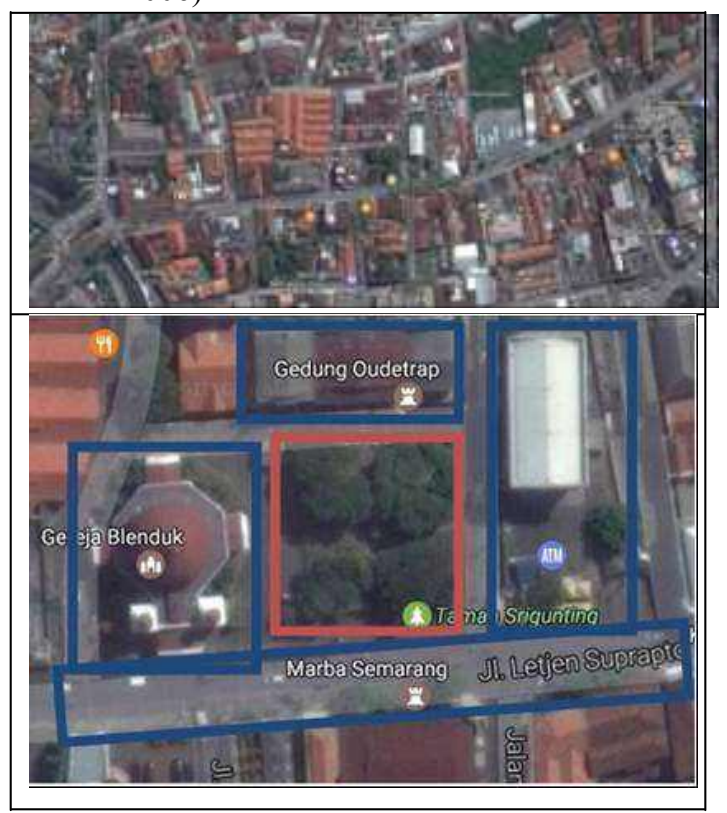

Gambar 2 :Peta lokasi dan detail taman Srigunting (google map) dan obyek pengamatan : profil aktifitas pemakai taman dan kebutuhan energy.

\section{METODA PENELITIAN}

Metoda ini dilakukan dengan melalui pengukuran lapangan atas performa thermal dan profil konsumsi energy listriknya pada suatu kawasan di kota Lama Semarang yakni kawasan Taman Sri Gunting di kota Lama Semarang. Suatu bentuk pendekatan mix method, yaitu pendekatan kuantitatif dan pendekatan kualitatif. Metode kuantitatif digunakan untuk mengukur performa thermal. Hasil pengambilan data di lapangan digunakan sebagai data. Evaluasi fungsi thermal dilakukan berdasarkan pada analisa suhu, kelembabapan dan kecepatan udara serta profil dari pelakunya (aktifitas dan gender). Sedangkan untuk mengukur profil energinya dilakukan dengan pengukuran dan pengamatan terhadap titik-titik lampu yang tersebar di area taman ini.

Secara diagramatis, tahapan pengukuran dan pembahasan yang dilakukan dapat dilihat pada tabel diatas.

Tabel 1 : Skema tahap pengamatan dan pengukuran lapangan

\begin{tabular}{|c|c|c|}
\hline & tahap & kegiatan \\
\hline 1 & $\begin{array}{l}\text { Pengamatan } \\
\text { aspek } \\
\text { kenyaman } \\
\text { an termal }\end{array}$ & $\begin{array}{l}\text { Mengamati aspek iklim mikro (suhu, } \\
\text { kecepatan udara dan kelembaban) pada } \\
\text { perbedaan waktu (siang dan malam) } \\
\text { Mengamati pengelompokan pola aktifitas } \\
\text { disekitar titik penerangan Mengamati } \\
\text { ragam aktifitas di dalam taman } \\
\text { Mengamati pengelompokan pelaku } \\
\text { berdasarkan gender, ras dan budaya }\end{array}$ \\
\hline 2 & $\begin{array}{l}\text { Pengamatan } \\
\text { aspek } \\
\text { Konsu } \\
\text { msi } \\
\text { Energi }\end{array}$ & $\begin{array}{l}\text { Mengamati letak dan jumlah titik lampu. } \\
\text { Mengamati jenis dan jumlah lampu. } \\
\text { Mengamati lama waktu penggunaan } \\
\text { lampu. } \\
\text { Mengamati aktifitas disekitar lampu. } \\
\text { Mencari informasi tambahan berupa daya } \\
\text { lampu melalui web internet. }\end{array}$ \\
\hline
\end{tabular}

\section{HASIL DAN PEMBAHASAN}

Terdapat 3 (tiga) tema bahasan dalam paparan ini, yaitu terkait dengan profil iklim mikro di taman Sri gunting, sensasi kenyamanan pelaku aktifitas didalamnya dan hubungan antara kenyamanan dan profil energy.

1. Profil Iklim kota Semarang dan lingkungan Taman Srigunting

profil iklim kota Semarang sepanjang tahun rata-rata suhu udara nya sebesar $26.6^{\circ} \mathrm{C}$, dengan suhu minimum rata-ratanya $21,7^{\circ} \mathrm{C}$ dan suhu rata-rata maksimumnya $31,8{ }^{\circ} \mathrm{C}$. Sedangkan kondisi saat pengukuran yang dilakukan pada siang hari hingga malam hari, didapatkan profil suhu udara rata- ratanya sebesar $31,6^{\circ} \mathrm{C}$ (minimum $28,7^{\circ} \mathrm{C}$, dan maksimum $34,8^{\circ} \mathrm{C}$,), dengan kelembaban rata-rata66\% (minimum 57\% dan maksimum 76\%).

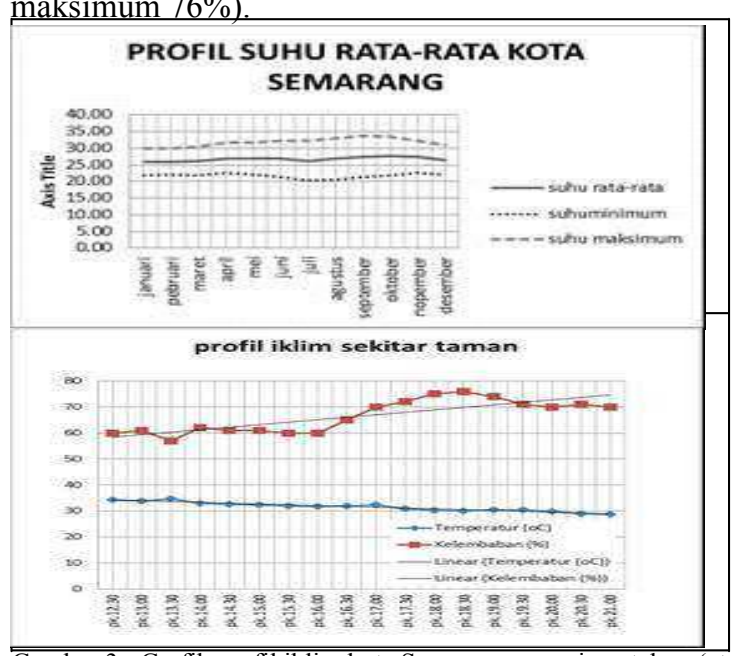

Gambar 3 : Grafik profil iklim kota Semarang sepanjang tahun (atasi) dan profiliklim mikro seputar taman dari siang sampai malam hari (bawah)

Suhu udara mencapai maksimim $(34,8 \mathrm{C})$ dicatat pada kondisi siang hari pk 13.30 dan minimumnya $(28,7 \mathrm{C})$ dicatat pada malam hari pk 21.00 WIB. Dan sebaliknya, 
bahwa kelembaban udara mencapai maksimim (76\%) dicatat pada kondisi magrib hari pk 18.30 dan minimumnya $57 \%$ dicatat pada siang hari pk 13.30 WIB.

Dan dapat dikatakan bahwa profil suhu dan kelembaban mencapai kondisi panas dan kering dicatat pada pk 13.30 WIB ( $34,8 \mathrm{C}$ dan 57\%). Selanjutnya, Taman Srigunting memiliki hasil Kelembaban Udara total rata-rata $65,5 \%$, dengan Kelembaban Udara Minimal $57 \%$ dan Kelembaban Udara Maksimal $76 \%$. Dari data penelitian diketahui bahwa pada sore dan malam hari memiliki Kelembaban Udara lebih tinggi dari pada siang hari, yaitu terjadi pada pukul 18:59 WIB.

2. Profil persepsi kenyamamana termal ruang luar pelaku di Taman Srigunting

Dari jajak pendapat terhadap 72 responden yang sedang beraktifitas di Taman Srigunting diketahui bahwa 24/72 responden (33\%) memberikan pilihan merasa sejuk, 29/72 responden (40\%) memberikan pilihan diatas nyaman (netral), dan 19/72 responden (27\%) memberikan pilihan hangat. Data tersebut memperlihatkan, secara rata- rata bahwa lebih banyak responden yang merasakan "sejuk dan nyaman" dibandingkan merasakan " hangat". Perasaan rasa „sejuk pada siang hari bias dikarenakan aktifitas pada siang hari masih terlinding dari pancaran sinar matahari, karena disekitar pepohopnan ataupun terkena bayangan bangunan sekitarnya.

Karakteristik responden yang diamati dalam pengamatan ii berdasarkan jenis kelamin, usia, domisili pada 4 titik taman Srigunting ini, selama 9 jam (dari pk 12.30 WIB hingga 21,00 WIB) telah didapat total responden 72 orang.

Lokasi taman yang berada didekat gereja Blenduk yang juga menjadi ikon dari kawasan Kota Lama Semarang dan atmosfir historik yang ditimbulkan maupun fasilitas yang tersedia, diduga meningkatkan minat pengunjung terutama kelompok usia remaja (15-24 tahun) untuk berkunjung ke Taman Srigunting. Sebagai pusat pemerintahan masa kolonial Belanda di Semarang, wilayah Kota Lama Semarang umumnya didominasi oleh struktur bangunan kolonial yang sudah disesuaikan dengan iklim lokal.

Dari hasil penyebaran kuisioner didapatkan pengunjung taman sebanyak $42 \%$ laki-laki dan $58 \%$ perempuan dari total 36 responden. Sebanyak

$30,56 \%$ perempuan memilih pilihan merasakan nyaman, $19,44 \%$ orang merasa sejuk, dan $8,33 \%$ orang merasa hangat. Sebanyak 22,22\% laki-laki memilih pilihan merasakan nyaman, $11,1 \%$ orang memilih dibawah nyaman, dan $8,33 \%$ orang memilih diatas nyaman.

Berdasarkan data pengamatan, responden yang berasal dari luar wilayah Kota Semarang berjumlah sebanyak
$50 \%$ orang dan dari Kota Semarang sebanyak 50\% orang dari total 36 reponden. Responden dari luar semarang sebanyak $33,33 \%$ orang memilih pilihan merasa nyaman, $8,33 \%$ orang memilih dibawah nyaman, dan $8,33 \%$ orang memilih diatas nyaman. Responden dari Kota Semarang sebanyak 19,44\% orang memilih pilihan merasa nyaman, $22,22 \%$ orang memilih dibawah nyaman, dan $8,33 \%$ orang memilih diatas nyaman.

Dari hasil pengamatan didapat bahwa pengunjung yang berdomisili di luar Semarang lebih banyak merasa sejuk, sedangkan pengunjung berdomisili Semarang lebih banyak memilih merasa nyaman. Secara rata-rata berdasarkan domisili, lebih banyak pengunjung taman yang merasa "sejuk dan nyaman"

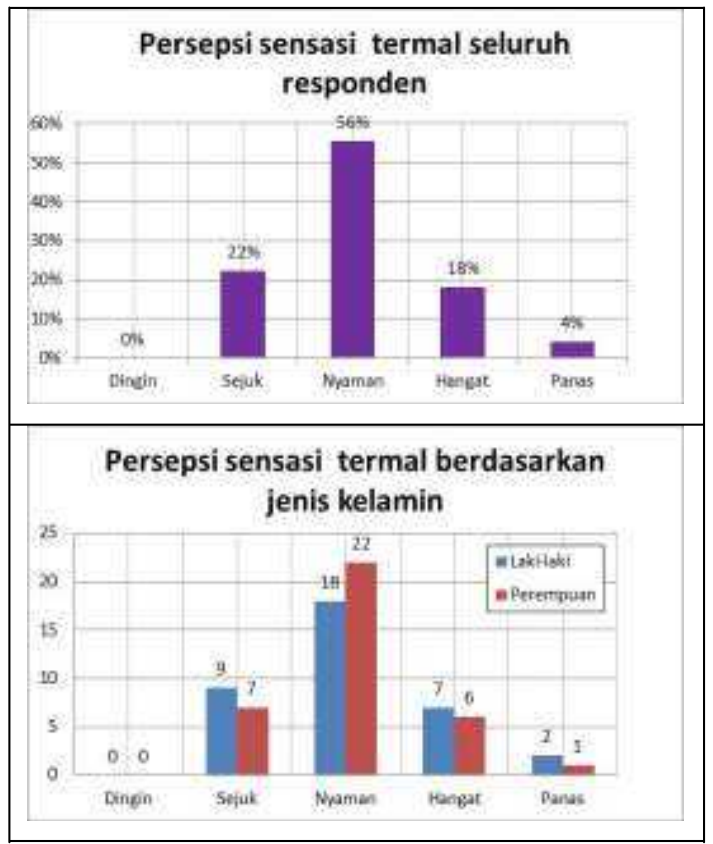

Gambar 4 :Grafik profil kenyamanan pengunjung

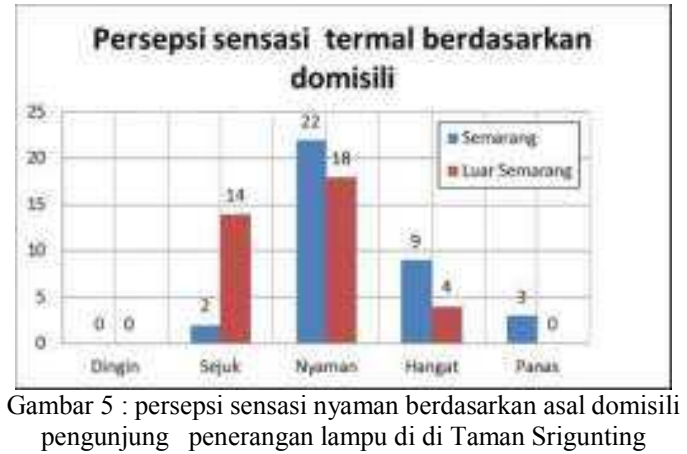

3. Karakter aktifitas seputar penerangan lampu di di Taman Srigunting 
- Karakteristik ragam penerangan pada Taman Srigunting

Jenis-jenis lampu yang terdapat pada area Taman Srigunting dan sekitarnya dalam radius 3 meter dan letak titiknya dapat dilihat pada gambar dibawah ini. Dimana penjelasan detail tentang ilustrasi dari sebaran dan jenis lampu dalam taman diatas adalah sebagai berikut :

Lampu Tembak (gambar a), Lampu tembak pada Taman Srigunting terdapat 8 lampu yang tersebar pada 2 titik. Titik pertama terdapat 6 lampu pada tengahtengah taman, pada titik ini lampu menyorot ke seluruh area taman dan bangunan-bangunan di sekitar taman. Titik ini juga merupakan titik dengan penyinaran paling terang, sehingga banyak masyarakat yang berfoto-foto pada titik ini karena pada titik ini memiliki pencahayaan yang cukup terang untuk berfoto dengan latar taman maupun bangunan di sekitar taman. Dua lampu berikutnya berada pada tepi sisi taman. Lampu tembak pada titik ini menyorot ke arah gedung Oudetrap.

Lampu Taman (gambar b), Lampu taman pada Taman Srigunting terdapat pada 12 titik di sekeliling tepi taman, dengan 2 buah lampu pada masing-masing titiknya. Lampu taman ini berfungsi untuk menyinari area plaza. Terdapat 4 plaza pada Taman Srigunting dengan 3 titik lampu untuk setiap plazanya. Jenis lampu yang digunakan ialah lampu jari dengan daya yang kemudian ditutup menggunakan kap lampu taman.

Lampu Sorot (gambar c), Lampu sorot pada Taman Srigunting terdapat pada 4 titik pada masing-masing plaza. Pada setiap titik terdapat 4 lampu yang mengelilingi dan menyorot ke arah pohon pada masingmasing plaza. Jenis lampu yang digunakan adalah lampu PAR RGB LED.

Lampu Hias Meteor (gambar d), Lampu hias meteor pada Taman Srigunting terdapat pada 4 titik pada masing-masing plasa. Lokasinya menggantung pada ranting- ranting pohon. Pada setiap titik terdapat 30 lampu hias meteor.

Lampu Jalan (lihat gambar a), lampu jalan pada area ini ialah lampu yang terdapat pada trotoar sekitar Taman Srigunting. Jenis lampu ini terdapat 3 titik dengan lampu yang digunakan ialah lampu jenis jari yang kemudian ditutup dengan kap lampu jalan. Namun yang terdapat pada lokasi lampu jalan ini dalam kondisi mati seluruhnya, karena penerangan yang berasal dari lampu tembak dan lampu PJU sudah cukup menerangi area trotoar.

Lampu PJU (lihat gambar b), Lampu PJU ini terdapat di 2 titik pada sisi sebelah selatan dan timur Taman Srigunting. Lampu jalan PJU ini berfungsi untuk menerangi jalan sekitar Taman Srigunting.

Lampu Kios (lihat gambar c), pada sisi sebela h timur taman terdapat kios barang- barang antic. Terdapat 10 kios dalam radius

3 meter dan terdapat 1 lampu jenis jari pada masingmasing kiosnya.

Lampu Tembak (lihat gambar d), berada diposisi central dari taman, berjumlah 1 dengan ketinggian yang relative tinggi dibanding lampu-lampu taman lainnya (setara lampu LPU)

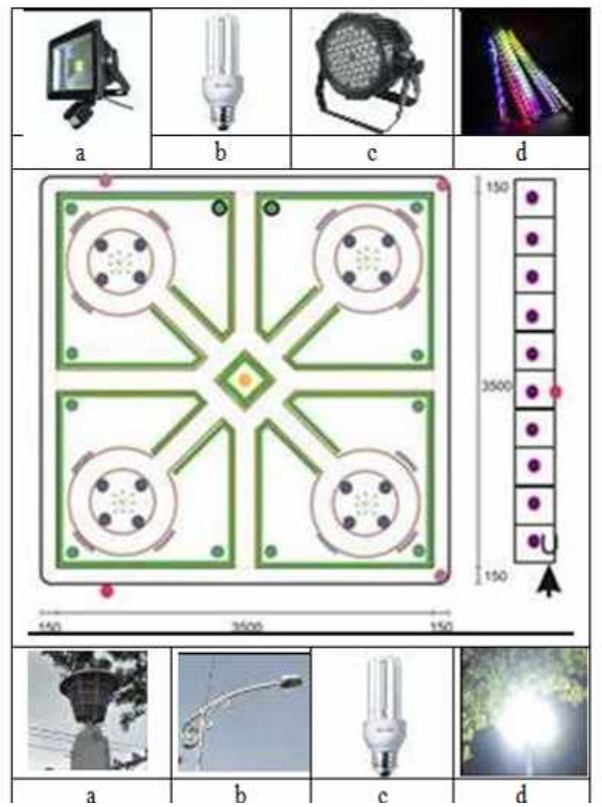

Gambar 6 : Profil perangkat penerangan di dalam taman (atas) dan di luar taman (bawah)

- Karakteristik penerangan dan aktifitas pada malam hari di Taman Srigunting

Taman Srigunting merupakan taman aktif pasif, yaitu taman berfungsi untuk dinikmati keindahannya, namun terdapat pula kegiatan aktif yang diadakan periodikal dalam waktu-waktu tertentu. Pada Taman Srigunting kegiatan yang paling menonjol ialah fotografi. Banyak hal yang dapat menyebabkan fotografi sebagai kegiatan utama pada Taman Srigunting, salah satu Taman Srigunting terletak pada kawasan cagar budaya Kota Lama yang mana memiliki bangunanbangunan kuno yang unik untuk difoto.

Pada Titik A, asumsi energi yang dikonsumsi jika lampu dalam keadaan nyala semua adalah sebesar 48.000 wh atau $48 \mathrm{kwh}$. Aktifitas yang terdapat di sekitar titik A cenderung aktif yaitu berjalan dan berfoto- foto. Titik A merupakan titik dengan penerangan paling terang.

Pada Titik B, asumsi energi yang dikonsumsi jika lampu dalam keadaan nyala semua adalah sebesar 
832 wh atau 0,832 kwh pada tiap titiknya. Aktifitas yang terdapat di sekitar titik B cenderung pasif yaitu duduk dan menikmati keindahan taman. Titik B merupakan titik dengan tingkat penerangan paling rendah.

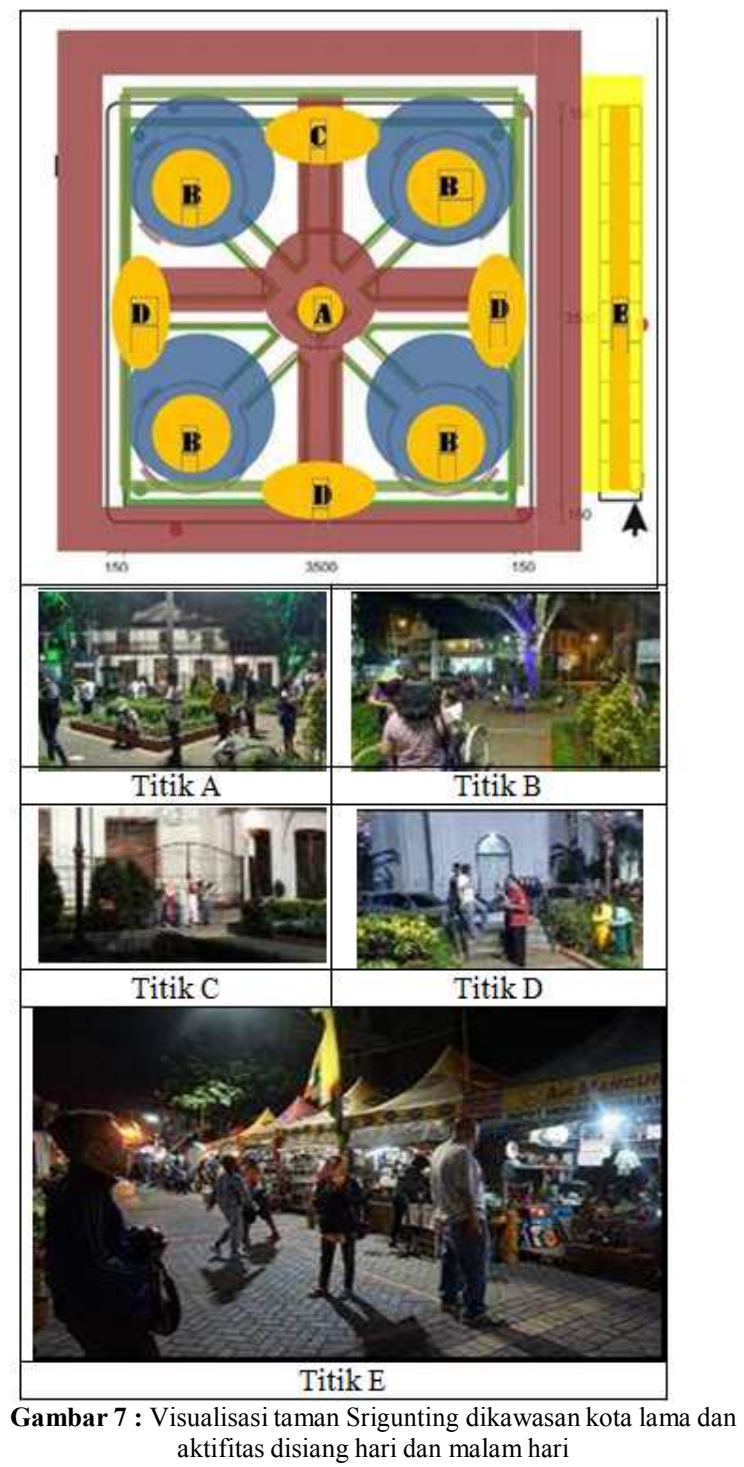

Pada Titik C, asumsi energi yang dikonsumsi jika lampu dalam keadaan nyala semua adalah sebesar 1092 wh atau $1,092 \mathrm{kwh}$. Aktifitas yang terdapat di sekitar titik C tidak seaktif pada titik A karena lampu tembak hanya menyorot ke arah utara, arah gedung Oudetrap sehingga kegiatan fotografi hanya berada pada sisi utara titik $\mathrm{C}$.

Pada Titik D, asumsi energi yang dikonsumsi jika lampu dalam keadaan nyala semua adalah sebesar 92 wh atau 0,092 kwh pada tiap titiknya.. Aktifitas yang terdapat di sekitar titik D tidak terlalu aktif, hanya lalu lalang orang berjalan saja karena titik D merupakan akses masuk menuju taman.

Pada Titik E, asumsi energi yang dikonsumsi jika lampu dalam keadaan nyala semua adalah sebesar 230 wh atau 0,23 kwh. Aktifitas yang terdapat di sekitar titik E juga tidak seaktif pada titik A, aktifitasnya jualbeli dan melakukan kegiatan fotografi

\section{KESIMPULAN}

- Taman Srigunting merupakan taman aktif pasif, yaitu taman berfungsi untuk dinikmati keindahannya, namun terdapat pula kegiatan aktif yang diadakan periodikal dalam waktu- waktu tertentu. Kegiatan yang paling menonjol ialah fotografi hal ini bisa disebabkan karena lokasinya pada aera wisata di kawasan cagar budaya Kota Lama Semarang yang kaya akan keragaman bangunan-bangunan kuno.

- Keberadaan taman disuatu kawasan akan memberi dampak penurunan iklim mikro sebagai berikut : Aspek kelembaban,: tingkat kelembabannya pada situasi menjelang malam, dari $57 \%$ pada siang hari menjadi $76 \%$ pada malam hari. Sedangkan aspek suhu udaranya dari 34,8C menjadi 28,7C.

- Kondisi iklim mikro tersebut signifikan dengan sensasi kenyamanan dari para pengunjung, bahwa $56 \%$ menyatakan nyaman dan hanya $4 \%$ yang menyatakan sensasi kepanasan di kawasan kota lama Semarang.

\section{UCAPAN TERIMA KASIH}

Makalah ini merupakan hasil skim Penelitian Dasar yang dikoordinir Departement Arsitektur Fakultas Teknik (DAFT) dengan dana DIPA Fakultas Teknik Universitas Diponegoro tahun 2017. Kegiatan ini telah tertuang dalam SK Dekan FT Undip No.170/SK/UN7.3.3/V/2017 tertanggal 15 mei 2017. Untuk itu kami ucapkan terimakasih pada semua yang telah membantu dan memfasilitasi semuanya sehingga terselesaikan penelitian ini.

\section{DAFTAR PUSTAKA}

Ahmad, R. J., \& Hidayat, M. S. (n.d.). "Tingkat Kenyamanan Termal Bagi Pengguna Taman di Jakarta"

Amin, M., Danusputra, H., \& Prianto, E, 2004. Pengaruh Bukaan Terhadap Kenyamanan Thermal pada Bangunan Publik di Daerah Tropis. Studi kasus: Masjid Raya Al-Mashun Medan", Laporan Tesis MTA Undip.Hovmand, 
S. (1995). Fluidized Bed Drying. In Mujumdar, A.S. (Ed.) Handbook of Industrial Drying (pp.195-248). 2nd Ed. New York: Marcel Dekker

D.Brown, Robert, and Terry J.Gillespie. , 1995.Microclimatic Lanscape Design.

Canada: John Wiley \& Sons,Inc,

DitjenPRDPU, 2008. PERATURAN MENTERI

PEKERJAAN UMUM NOMOR :

05/PRT/M/2008 Tentang Pedoman Penyediaan dan Pemanfaatan Ruang Terbuka Hijau di Kawasan Perkotaan. Jakarta: Direktorat Jendral Penataan Ruang Departeman Pekerjaan Umum.

Frick, Heinz, and Antonius Darmawan,2007. Ilmu

Fisika Bangunan. Jogjakarta: Kanisius, Hakim, Rustam. "Rancangan Visual Lansekap

Jalan. Jakarta: Bumi Aksara", 2006.

Hawa, S. 2016. Penentuan Indeks Kenyamanan Ruang Terbuka Hijau dan Lahan Terbangun di Kota Bogor",

Istiawan, S., \& Kencana, I. 2006. Ruang. Jakarta: Griya Kreasi

Lippsmeier, Georg. 1994. Bangunan Tropis. Jakarta: Erlangga,

Karyono, Tri Harso, 2010. Green Arsitektur- Pengantar Pemahaman Arsitektur Hijau di Indonesia. Jakarta: Rajawali Pers.

Kolcaba, K. 2003. Comfort theory and practice: a vision for holistic health care and research. New York: Springer Publishing Company.

Muhammad, Huda dan Prianto, Eddy 2016, Kenyamanan thermal taman Srigunting,, laporan Seminar DAFT Undip

Pemkotsemarang. 2016, Gedung Marba Kota Lama. Retrieved April 2017, from pemkotsemarang:

https://pemkotsemarang2016.wordpress.com/20 16/12/11/gedung-marba-kota-lama/ Kirmanto, D. 2008. Peraturan Menteri PekerjaUmum Nomor : 05/PRT/M/2008 Tentang Pedoman Penyediaan Dan Pemanfaatan Ruang Terbuka Hijau Di Kawasan Perkotaan. Jakarta: Direktorat Jenderal Penataan Ruang Departemen Pekerja Umum.

Prianto, Eddy, and Patrick Depecker, 2003. Optimazion of Architectural Design Elements in Tropical Humid Region with Thermal Comfort Approach. Energy and Buildings: 273280.

Prianto. E, 2007, Rumah Tropis Hemat Energi, bentuk keperdulian Global Warming, Riptek, 1-10

Prianto, E., \& Depecker, P. (2002). "Characteristic of Air Flow as The Effect of Balcony, Opening Design and Internal Division on Indoor Velocity".

Sangkertadi. (2013). "Kenyamanan Termis
diRuang Luar Beriklim Tropis Lembab", Satwiko, P. 2004. Fisika Bangunan 2. Yogyakarta: Penerbit Andi.

Soegijanto. 1998. Bangunan di Indonesia dengan iklm tropis lembab ditinjau dari aspek fisika bangunan. Bandung: DIKTI

SNI 03-6169-2011, 2017, Prosedur Audit Energi

Pada Banguna $n$ Gedung

Susiloarifin, Hadi, dan Nurhayati. 1994, Pemeliharaan Taman. Jakarta: Penebar Swadaya.

Widjayanti. 2007. Profil konsumsi energi listrik pada rumah tinggal (Studi Kasus Rumah Desain Minimalis Ditinjau Dari Aspek Pencahayaan Buatan). Jurnal Ilmiah Perancangan Kota dan Permukiman , 2-3.

Yunika, T. (2012, May 23). Standar dan Fungsi Taman Kota. Retrieved March 31, 2017, from Taman Kota: http://tarayunika.blogspot.co.id/2012/05/stan dar-dan-fungsi-taman-kota.html 